Journal of Economics and Behavioral Studies

Vol. 4, No. 8, pp. 436-448, Aug 2012 (ISSN: 2220-6140)

\title{
Broad Money Demand in Mauritius with Implications for Monetary Policy
}

\author{
Indranarain Ramlall \\ University of Mauritius, Réduit, Mauritius \\ i.ramlall@uom.ac.mu
}

\begin{abstract}
This paper employs ECM approach to investigate the long run and short-run components of the broad money demand function in Mauritius for the period spanning from 2000 to 2009. To the author's best knowledge, no study has been undertaken over broad money in Mauritius since 1992, with an update being long overdue. Results show that M2 is positively elastic with respect to GDP, with the elasticity coefficient revolving around $2.80 \%$, clearly showing that Mauritius is not endowed with a fully developed financial system with monetization moving faster than output. The low adjustment coefficient for VECM furthers substantiates the fact that there is indeed a lack of alternative assets to M2 and above all fully justifies the transition from monetary targeting to interest rate targeting. Evidence is found in favor of foreign asset substitution but only through the exchange rate channel. Findings further show that the local stock market does not act as a substitute to local money holdings. Overall, the study points out a rather stable demand for money function in Mauritius so that the monetary authority can contemplate using it as a complementary tool but chiefly for long-run policy assessments.
\end{abstract}

Keywords: Money demand, Mauritius, Vector Error-Correction Model

\section{Introduction}

All central bankers agree that monetary transmission mechanism is complex to the effect that some simple rules of thumb are considered as vital elements in fine-tuning or crosschecking their decisions. In that respect, following the widely agreed fact that inflation is always a monetary phenomenon, it becomes sensible to consider the money demand function with a view of ending up with an enhanced monetary policy decision process. It is with this motive in mind that the current research proceeds towards analyzing the money demand function in Mauritius. Indeed, in the early stage of development, Mauritius stressed on its monetary aggregates to subsequently move towards interest rate targeting under its new monetary policy framework, though credit aggregates are still being monitored. The current study investigates as to whether broad money (M2) constitutes a viable monetary policy tool in Mauritius. As financial liberalization gained momentum in Mauritius, the Bank of Mauritius resorted towards price variables such as interest rates for monetary policy implementation rather than monetary targeting. Indeed, there has been greater dependence on open-market operations to affect short-term interest rates as financial markets have developed with a move away from achieving broad money targets by limiting bank lending through moral suasion, or through changes in reserve requirements. In fact, the current monetary policy framework in Mauritius resorts towards a combination of open market operations and reserve requirements for liquidity management. The intermediate target is the Key Repo rate, which is adjusted following in line with interest rate differentials in the case of major trading partners, exchange rate movements and inflation above a specified tolerance level. Moreover, though Mauritius has been subject to major changes in its monetary policy framework with the most recent ones being in 1999 and 2006, yet, it is still in a learning process (with the objective of moving steadily towards the inflation targeting where an arsenal of information constitutes a prerequisite.

To date, considerable work, both theoretical and empirical, have been undertaken with respect to the stability of the broad money demand function. However, for Mauritius, there is only Simmons (1992) who analyzed its demand for money function, including four other African countries. However, since then, many fundamental changes have been brought to Mauritius's financial system, which is likely to significantly change the structure of the money demand function so that Simmons' findings can now be deemed as obsolete. In fact, with managed floating exchange rate system adhered to in 1994 and developments in the local capital markets, let alone positive synergies in the financial system, all of which are susceptible to generate a positive 
impact on the demand for money. In a parallel manner, the local stock market has steadily developed itself over the years. Consequently, bearing in mind these fundamental changes, an update for the broad money demand function in Mauritius is long overdue. Another motive for analyzing the money demand function in Mauritius follows from the recent study of Tsangarides (2010) who finds that the current monetary policy tool generates a rather weak transmission mechanism with the policy interest rate having a weak impact on output. Consequently, it becomes interesting to know whether there is a stable money demand, which can be used as a complementary tool in framing sound monetary policy decisions. Consequently, this paper contributes significantly in providing new updates on money demand, let alone uncovering any feasible information for sound monetary policy implementation.

The underlying rationale for having a stable money demand function is that it enables money growth rates to be sound predictors of future inflation and output trends. Alternatively, stated, monetary targeting to control inflation hinges predominantly on the stability and predictability of money demand. Only then can monetary authorities have a certain level of confidence so that in the case the actual money growth is above target, there is likely to be upward pressure on prices and consequently some proper contractionary monetary policy actions can be envisaged. On the other hand, if the money demand behavior is not predictable, this is synonymous with the monetary authorities being unable to know whether "excess" money growth reflects a permanent or temporary shift in the private sector's desire to hold money balances. Still, however, even if, money growth rates do not constitute sound leading indicators of future inflation, it may be sensible to monitor them under a wide set of variables because money has a vital say in the Mauritian financial system, which is still in an ongoing development stage. The remainder of the paper is structured as follows. The next section presents the literature review on broad money demand function. Section 3 then describes the Mauritian economy along with its monetary policy framework. Section 4 labels the data and methodology employed in the study, which is then followed by section 5 that deals with the results obtained. Finally, section 6 concludes.

\section{Literature Review}

A stable money demand has been stressed by policy-makers when it comes to a proper conduct of monetary policy whereby central banks can change their monetary aggregates to generate predictable impacts on output, interest rates and prices. The theory of money demand points out that the demand for money is basically for real balances with different variables used to account for the level of economic activity, inflation rate and a set of opportunity cost variables employed to represent both local and foreign asset substitution. As far as the econometric methodology is concern, VECM has been widely used in empirical studies due to its ability to model both the long run and short-run determinants. In the 1980s, financial innovations in major financial centers represented the main reason behind the instability of narrow money demand. Money has four basic functions by acting as a medium of exchange, a store of value, a unit of account and a source for deferred payment. The literature on money demand comprises of different theories. At the outset, the classical economists such as Schumpeter (1954) considers money merely as a veil to enable economic activities to occur since it is used as a numeraire to price products with no real effects on economic variables. Money removes the problem of barter system, which was buffeted by a lack of double coincidence of wants. Then, the quantity theory of money took birth and which had two versions, separately developed by Fisher (1911) and Pigou (1917). Fisher (1911) version is labeled as the equation of equation where MV = PT, i.e. the product of quantity of money in circulation and the velocity of circulation is equal to the product of the price level and the volume of transactions. In case $\mathrm{V}$ and $\mathrm{T}$ are assumed to be stable, any increase in $\mathrm{M}$ will entail a proportionate rise in Pigou (1917) later developed its own version which is also referred to as the Cambridge approach where MV = Py where V refers to income velocity of circulation. Since V is fixed and y is at full employment, again, any increase in $M$ will entail a proportionate rise in Later, Keynes $(1930,1936)$ radically change the money demand concept from "an all spending state" to "a hoarding state" since he views that there are three motives for holding money, in particular, the transactionary motive, the precautionary motive and the speculative motive. The transactionary demand for money occurs on the back of non-synchronization of receipts and payments and its demand function is positively related to the level of income. In a parallel manner, the precautionary demand for money is also positively related to the level of income but it is based on the need for holding money to cater for any unforeseen contingencies as and when required. The most appealing part of Keynes theory is the speculative demand for money, which is based on interest rate level 
and with an inverse relationship. Then came the post-Keynes theories of money demand, which comprise of, among others, Baumol (1952), and Tobin (1956) inventory-theoretic approach. The next section considers some of the major changes that have been brought to monetary policy framework in Mauritius.

Mauritian economy and Monetary Policy Conduct: Since its independence in 1968, Mauritius has been an example for most African countries in terms of steady growth in national income along with social, political and economic stability. The Stock Exchange of Mauritius began its operation in 1989 and has since been subject to major innovations such as daily trading, extending its trading time, listing of foreign companies and recently it has been announced that futures will now be also traded. Mauritius had a population of about $1,275,032$ with a real GDP growth rate of 2.8 per cent in 2009. As at end March 2010, the financial system in Mauritius comprised of 18 banks, 12 non-bank deposit taking institutions, 14 moneychangers and 5 foreign exchange dealers. Mauritius has a bank-based financial system whereby the banks contribute around $70 \%$ of the total assets in the financial system. Furthermore, Islamic financing is also gaining pace in Mauritius. The budget deficit hovered around 3.4 per cent of GDP for the six months ended December 2009. For the year 2009, the following sectors contributed more than $10 \%$ of total GDP, namely, the manufacturing sector, the wholesale and retail trade sector, the transport sector, the real estate sector and the financial intermediation sector, contributing about $19.42 \%, 12.02 \%, 10.91 \%, 11.86 \%$ and $11.65 \%$, respectively. Per capita GDP rose by about $16.35 \%$, from Rs 164,172 to Rs 191,008 in 2009. In 2007, Mauritius ranked 81 out of 182 countries under the UN Human Development Index. The Mauritian financial sector has been deepening slowly with the ratio of M2/GDP rising by about 28\% from March 2000 to September 2009. As at February 2010, the import coverage in terms of the number of weeks hovered around 47.5, which signified that Mauritius is well poised to withstand any external shocks. Although, there is a single license for both Segment A and Segment B banks, yet, no conspicuous penetration has been noted in each case though, as the US Subprime crisis unfolded, it led to more effects on Segment B activities relative to those of Segment A. The Mauritian financial system, apart from having banks, a stock market, will now have a derivatives market. The Financial Services Commission has already licensed the Global Board of Trade to establish in Mauritius with a view of tapping on the African market in case of derivatives trading.

However, Mauritius has not been spared from the US subprime crisis as witnessed by a fall in output growth from 4.2 per cent in 2008 to less than 2 per cent in 2009 attributable to contraction in the tourism, textile and construction sectors. Nonetheless, the country fared up well on the back of prompt measures taken by the government in the form of fiscal stimulus package of about Rs 10 billion acting mostly like automatic stabilizers, loosening of the Key Repo rate by a hefty 250 basis points and a robust and resilient banking sector (with no exposure to toxic assets) in the form of solid capital adequacy, profitability and liquidity ratios. In a parallel manner, to self-discipline its public debt level, a public debt management act was issued whereby the objective has been to reduce the public debt to 50 per cent of GDP by the year 2013. In general, eased monetary policy coupled with fiscal stimulus packages have supported the economy following the impacts of the crisis despite the fact that future output growth will heavily depend on the strength of international economic recovery. The main objective of the Bank of Mauritius is geared towards maintenance of price stability and to promote an orderly and balanced economic development. Initially, Mauritius adhered to a system of direct controls with the introduction of credit ceilings in 1973 and administered interest rates. Later, Mauritius embarked on indirect monetary by introducing important reforms, which include, among others, liberalization of the interest rates in 1988, the elimination of credit controls in 1993, suspension of exchange controls in 1994 and linking the bank rate to latest average bill rate to further move towards market-determined interest rates. A Reserve Money Program and a Liquidity Forecasting Framework was set up in 1996. The monetary policy framework underwent a major change in 1999 when the Lombard Facility was introduced to indicate the main stance of monetary policy in Mauritius. Prior to 1999, the monetary policy framework was considered to be imbued with problems since it was not possible to disentangle movements in the bank rate due to monetary policy changes from movements due to excess liquidity prevailing in the monetary circuit. Indeed, the Bank rate, which was determined by the market at the weekly auctions of Treasury bills, was also used to reflect the stance of monetary policy.

However, the movements in the bank rate failed to really reflect the stance of monetary policy. Consequently, the rate attached to the Lombard Facility (known as Lombard rate) reflected the interest rate that commercial banks used under lender of last resort so that such rate could clearly signaled the central bank's 
monetary policy stance. On the other hand, to properly regulate liquidity between weekly Treasury bills auctions, repurchase and reverse repurchase operations were used as complementary tools. Therefore, market participants could clearly distinguish between policy-induced interest rate changes from liquidityinduced changes. However, on December 2006, BOM started with a new framework for its monetary policy with the Repo Rate replacing the Lombard rate as the signaling stance for monetary policy. Under the new framework, the Bank of Mauritius pursues a monetary policy strategy based on two approaches. The first approach factors in economic analysis that considers both short and medium term risks to price stability. The second approach evaluates monetary developments and the associated long-term risks to price stability. A corridor of 50 basis points above and below has been set up to derive the ceiling and floor for overnight interbank interest rates. Moreover, in 2007, the corridor around the key Repo Rate has been widened from +/- 50 basis points to +/- 125 basis points. However, despite the new framework for monetary policy, there are some major problems that buffet an effective application of monetary policy in Mauritius. First, the money market is still not well developed with the secondary market still not operating, as it should have been in terms of amount and frequency of transactions.

\section{Methodology}

Money stock definitions differ for different countries by virtue of their level of financial development. For instance, industrial economies have a more encompassing definition like M3, M4 and M5. Nonetheless, M1 and M2 are commonly used. M1, also known as narrow money, represents currency with the public plus demand deposits with the banking system. Quasi-Money comprises of savings deposits, time deposits and foreign currency deposits. M2 is equal to M1 plus Quasi-Money. The most distinctive element that subsists between narrow money and broad money is that, while the former is readily available and transferable in daily transactions, broad money incorporates other forms of money for portfolio needs. For the current study, M2 is employed as the level of money stock to be in line with majority of empirical evidence on money demand. Above all, broad money is considered as it captures the process of liberalization and innovation in the financial system. The money market is in equilibrium in the end when the real money supply is equal to the real money demand. Money demand functions are analyzed using variables, which can be either in logarithmic form or in levels. In the former case, they are directly interpreted as elasticity's while, in the latter case, they represent the semi-elasticity. Long-run income elasticity is greater than one for many countries where the financial system is still underdeveloped and monetization is faster than output growth. In the case of industrial economies, the long-run income elasticity of demand for broad money is near one (see Knell and Stix, 2004). Money demand theories posit a relationship between the quantity of money demanded and a set of few important economic variables, which link money to the real sector of the economy. Money demand functions are often estimated in log liner form with monetary aggregates and scale variables taken in their either logarithms while other variables enter in levels or logarithm. Most empirical papers posit that the money demand function exhibits a positive relationship with Gross Domestic Product (Anuar, 1986, Habibullah, 1987, and Habibullah and Ghafar, 1989), industrial production index (Marashdeh, 1997 and Sriram, 1999) and a negative relationship with the interest rate variable (see Civcir, 2003; Laidler, 1993). For the current study, real gross domestic product is utilized as the measurement of income in this paper.

The standard theory of money demand states that:

$M / P=f(Y, R)$

Where

M: Nominal money demand, M2

P: Price level

Y: Scale variable for income and output

R: a vector of returns on different assets- real, local and foreign that represent the opportunity cost of holding money. The latter is usually captured as part of the portfolio framework and thereby comprises of the following variables:

- For real assets, the expected rate of inflation is employed. Since there is no data on expected inflation in Mauritius, actual inflation rate is thereby used. Friedman (1969) states that inflation constitutes a negative return for holding own money as it reduces its purchasing power. Subsequently, on the back of higher inflation, it is expected that real broad money demand will fall as economic players substitute real assets for money to ensure no major erosion in the value of their wealth. Indeed, while the real value of 
money depreciates under rising inflation, the real value of assets stays unchanged. Real assets are susceptible to play a significant role in individual's portfolio decision especially in developing countries.

- Two proxies are employed to denote local assets substitution, namely the 3-month Treasury bill yield and all-share index (SEMDEX) of the local equity market. For local assets, the savings rate is used to denote own rate of return on money holdings. Higher 3-month Treasury bill yield is likely to engender stronger money holdings. Based on asset substitution (as per $\mathrm{Wu}$ (2009)) and to derive a full-fledged model for the money demand function in Mauritius, SEMDEX is included as additional variable in the model. As at end September 2009, equity market capitalization over GDP hovered around 64 per cent, clearly showing that the local stock market may be an important substitute to money holdings. As a matter of fact, Sriram (2001) clearly points out that failure to provide due consideration to the selection of the proper variables and model specification led to poor results.

- For foreign assets, both foreign interest rates and expected rate of depreciation of the local currency are used. Because Mauritius moved to a managed floating system in 1994, it becomes interesting to analyse how integrated financial markets have been in terms of the money demand function. Indeed, as a small highly open economy with no capital controls, exchange rates have significant effects on the Mauritian economy. Sriram (1999) labels the portfolio shift between local and foreign money as the direct substitution effect based on exchange rate movements. Bahmani-Oskooee (1991) uses the Real Effective Exchange Rate while others such as Chowdhury (1995) and Ericsson and Sharma (1996) use the Nominal Effective Exchange Rate. However, due to absence of proper data on NEER for Mauritius, recourse is made towards the rupee price of the US Dollar. The rationale is that the exchange rate system in Mauritius is cantered towards the US Dollar.

On the other hand, he considers the indirect currency substitution for the foreign interest rate, which becomes vital in case foreign securities generate an important investment vehicle. The study employs LIBOR as the foreign interest rate. A negative relationship is postulated since a rise in foreign interest rate return will induce Mauritians to scale up their holdings in terms of foreign assets by correspondingly reducing their level of money holdings. From that respect, failure to include foreign considerations in the money demand function is susceptible to trigger model misspecification, which in turn distorts the long-run elasticity between GDP and broad money. Monthly data from January 2000 to September 2009 have been used for the analysis. Data after 2009 has been overlooked since the US Subprime crisis began to generate adverse effects onto the Mauritian economy so that results would then be deemed biased. SEM reflects the general broad market index of the Mauritian Stock Exchange Market. USD is used to capture the exchange rate impacts and is denominated against the Mauritian rupee. To capture local interest rate evolution, the 3-month Treasury bill yields are used while LIBOR is employed to incorporate the foreign interest rate counterpart. All data are described in table 1. M2 reflects the broad demand for money. CPI pertains to the Consumer Price Index, widely used to capture inflation. Multiplicative extrapolation technique has been employed to transform quarterly GDP data in its monthly form. While collecting the broad money data for Mauritius, it was found that there was a structural change as from December 2007. To ensure proper use of the available data, the change in values for M2 for January 2008 onwards were computed to adjust the data. Such approach preserves the short-term dynamics to thereby sieve out the true relationships among the variables in the model.

\section{Table 1: Definition of variables}

\begin{tabular}{ll}
\hline M2 & Natural logarithm of (M2/CPI) \\
GDP & Natural logarithm of (GDP/CPI) \\
CPI & Natural logarithm of (CPI) \\
SEM & Natural logarithm of (SEMDEX) \\
USD & Natural logarithm of (USD) \\
TB3 & Natural logarithm of (TB3) \\
LIBORUSD & Natural logarithm of (LIBORUSD) \\
\hline
\end{tabular}


Table 2: Descriptive Statistics

\begin{tabular}{lccllllc}
\hline & M2CPI & GDPCPI & CPI & SEMR & TB3 & USD & LIBORUSD \\
\hline Mean & 7.423465 & 6.106016 & 4.471525 & 6.567645 & 2.024203 & 3.389750 & 0.989943 \\
Median & 7.439815 & 6.105997 & 4.447727 & 6.540352 & 2.050270 & 3.388055 & 1.068153 \\
Maximum & 7.688118 & 6.333858 & 4.768988 & 7.607684 & 2.558002 & 3.546195 & 1.926072 \\
Minimum & 7.173953 & 5.903194 & 4.198508 & 5.831648 & 1.302913 & 3.247681 & -1.248691 \\
Std. Dev. & 0.152373 & 0.105007 & 0.178734 & 0.556006 & 0.290562 & 0.071986 & 0.706204 \\
Skewness & -0.097758 & -0.011433 & 0.245083 & 0.323122 & -0.365327 & -0.000305 & -0.669321 \\
Kurtosis & 1.751478 & 2.083655 & 1.836595 & 1.750995 & 2.202480 & 2.391088 & 2.959684 \\
Jarque-Bera & 7.785541 & 4.096029 & 7.769651 & 9.641020 & 5.703233 & 1.807526 & 8.743737 \\
Probability & 0.020389 & 0.128991 & 0.020551 & 0.008063 & 0.057751 & 0.405043 & 0.012628 \\
Observations & 117 & 117 & 117 & 117 & 117 & 117 & 117 \\
\hline
\end{tabular}

Table 3: Correlation Coefficients

\begin{tabular}{lccccccc}
\hline & M2CPI & GDPCPI & CPI & SEMR & TB3 & USD & LIBORUSD \\
\hline M2CPI & 1.000000 & 0.910874 & 0.960772 & 0.901881 & -0.411281 & 0.621165 & -0.207622 \\
GDPCPI & 0.910874 & 1.000000 & 0.899863 & 0.854265 & -0.279805 & 0.579008 & -0.185618 \\
CPI & 0.960772 & 0.899863 & 1.000000 & 0.941156 & -0.252228 & 0.591757 & -0.201610 \\
SEMR & 0.901881 & 0.854265 & 0.941156 & 1.000000 & -0.168363 & 0.426142 & 0.021218 \\
TB3 & -0.411281 & -0.279805 & -0.252228 & -0.168363 & 1.000000 & 0.004631 & 0.585602 \\
USD & 0.621165 & 0.579008 & 0.591757 & 0.426142 & 0.004631 & 1.000000 & -0.128837 \\
LIBORUSD & -0.207622 & -0.185618 & -0.201610 & 0.021218 & 0.585602 & -0.128837 & 1.000000 \\
\hline
\end{tabular}

Descriptive statistics for all the variables are shown in table 2 while table 3 depicts the correlation coefficients that subsist among the variables. A stochastic process is said to be stationary if its mean and variance are constant over time and the value of the covariance between the two times depends only on the distance or gap between the two time periods and not the actual time at which the covariance is calculated. Prior to implementing any co integration analysis, it is apt to test for stationary of each series under investigation. Table 4 shows that each variable is non-stationary in level but stationary in case it is firstdifferenced, making them eligible for co integration analysis. As Rasche and Johannes (1987), the series are not seasonally adjusted to shun the introduction of spurious autocorrelation from the standard seasonal adjustment techniques. In other words, the aim for not seasonally adjusting the data is to preserve the shortterm dynamics. Instead, seasonal dummies are employed in the analysis. Co integration technique under Johansen's (1991) approach is used to sieve out the long-run relationships that prevail among the interested variables. Tests of co integration are conducted for all variables under consideration. The lag order of the VAR is not known and is used based on Johansen procedure.

Table 4: Unit Root Tests

\begin{tabular}{lll}
\hline & ADF Test in Level & ADF test in first difference \\
\hline M2 & -0.4518 & $-12.6294^{* *}$ \\
GDP & -0.5021 & $-3.9966^{* *}$ \\
USD & -2.4477 & $-6.4889^{* *}$ \\
LIBORUSD & 0.2854 & $-6.0443^{* *}$ \\
CPI & 0.2976 & $-8.6743^{* *}$ \\
TB-3 & -1.8214 & $-8.0540^{* *}$ \\
SEMDEX & -0.0531 & $-7.9800^{* *}$ \\
\hline
\end{tabular}

** denotes statistical significance at the $1 \%$ level.

The error correction model is employed as the econometric methodology to estimate the money demand function for Mauritius. The greatest advent of such a technique is that it enables the researcher to simultaneously capture the long run and short-run dynamics of the model. Apart from capturing the long run and short-run dynamics of the model, ECM also enables to analyze the disequilibrium as a process of reverting towards the long-run model and hence, in essence, embeds important information. This clearly explains the rationale as to why ECM has been used for a plethora of studies by many researchers around the globe, let alone the fact that it is now considered as the workhorse of the money demand research. 


\section{Empirical Results}

When 8 lags are employed, it surfaces that there are two optimal lags under Schwarz information criterion and Hannan-Quinn information criterion. When these two optimal lags are employed under the first model comprising of all the non-stationary variables in levels forms, it transpires that there exists one co integrating equation at the $5 \%$ under both the trace test and the maximum-eigenvalue test. Consequently, the VECM model has been run but the exogeneity tests show that LIBORUSD and SEMR should be treated as exogenous variables. Hence, a new system was constructed excluding these two variables. However, again, it appears that now, that TB3 and USD are not statistically significant as long-run components of the model. Therefore, with the aim of deriving a parsimonious and enhanced model, a final VECM was run based comprising only of M2, CPI and GDP. Results show that under two optimal lags, there is one co integrating equation at the 5\% level with exogeneity tests showing that GDP is only weakly exogenous. Since the data was not seasonally adjusted because such profiteering may affect the dynamics in line with Wallis (1974), Ericsson, Hendry, and Tran (1994), Ericsson, and Sharma (1994), seasonal dummies have been used. However, none is found to be statistically significant. The final model is reported in table 5 with only the statistically significant variables being reported. As per the quantity theory of money, the long-run elasticity between GDP and broad money should be 1.0. However, the results show that, though, the demand for broad money in Mauritius is positively elastic with respect to GDP, yet, it is greater than two with an elasticity of 2.80 per cent, clearly depicting that the level of monetization is high in Mauritius. This clearly shows the extent of monetization in Mauritius and Baharumshah (2004) finds an income elasticity of 3.69 per cent in case of Malaysia with Dekle and Pradhan (1997), Majid (2004), and Dahalan (2004) reporting income elasticity of money demand higher than unity for developing countries. This implies that for the period under scrutiny, changes in real income have trailed behind, on average, a more than proportionate rise in the demand for real broad money.

Table 5: Empirical Results for Mauritius

\begin{tabular}{|c|c|}
\hline \multirow{2}{*}{\multicolumn{2}{|c|}{$\begin{array}{cc}\text { Speed of adjustment coefficient } & -0.0309 \\
& (-2.4512)^{* *} \\
\text { Impact of Long-Run Components on M2 }\end{array}$}} \\
\hline & \\
\hline GDPCPI(-1) & $\begin{array}{l}2.7991 \\
(69188)^{* *}\end{array}$ \\
\hline CPI $(-1)$ & $\begin{array}{l}-0.6468 \\
(-2.8699)^{* *}\end{array}$ \\
\hline Constant Term & 6.7774 \\
\hline Impact of Short-Run Comp & nts on $M 2$ \\
\hline Constant Term & $\begin{array}{l}0.0064 \\
(2.6589)^{* *}\end{array}$ \\
\hline D(M2CPI $(-1))$ & $\begin{array}{l}-0.3374 \\
(-3.0722)^{* *}\end{array}$ \\
\hline D(GDPCPI(-1)) & $\begin{array}{l}0.1552 \\
(3.9113)^{* *}\end{array}$ \\
\hline D(GDPCPI(-2)) & $\begin{array}{l}-0.1081 \\
(-2.2892)^{* *}\end{array}$ \\
\hline D(GDPCPI(-3)) & $\begin{array}{l}0.1317 \\
(2.0687)^{* *}\end{array}$ \\
\hline $\mathrm{D}(\mathrm{USD}(-1))$ & $\begin{array}{l}0.1261 \\
(2.3653)^{* *}\end{array}$ \\
\hline D(TB3) & $\begin{array}{l}-0.0457 \\
(-2.6726)^{* *}\end{array}$ \\
\hline R-squared & 0.3412 \\
\hline Adj. R-squared & 0.2701 \\
\hline F-statistic & 4.8027 \\
\hline Log likelihood & 360.5200 \\
\hline
\end{tabular}


Such a finding bodes well with those of Ramlall (2009) who finds that both debit and credit cards do not entail a major influence on the level of currency in circulation in Mauritius. The coefficient of the error correction mechanism (ECM) is - 0.03. This suggests that a very slow speed of adjustment of 3 percent to remaining disequilibrium. The negative effect signifies that lagged excess money holdings trigger smaller holdings of current money. Alternatively stated, the negative sign on ECM term is indicative of corrective actions undertaken by market players in the current period for the previous period's disequilibrium in money balances in view of converging towards the long-term equilibrium. Wu (2009) also finds a low adjustment coefficient of 1.1 per cent in the case of China while Taylor (1986), and Ericsson and Sharma (1996) find that the adjustment coefficients for ECM lie at $-0.26,-0.15,-0.20,-0.12$ and -0.08 for Netherlands, Germany, France, Argentina and Greece, respectively. The lower adjustment coefficients found for the developing countries is considered to represent the impact of a less developed financial system relative to advanced economies. The three-month Treasury bill yield does not affect broad money in the end but only in the short run. A $1 \%$ increase in three-month Treasury bill yield generates about -4.6 percent fall in M2 in the short-run. The negative effect is consistent with theoretical considerations whereby higher return on alternative local assets such as treasury bills deters money holdings. Because banks constitute the major bidders in the Treasury bill auctioning, in the short-run, their actions are susceptible to affect the level of broad money in the system. Results show that SEMDEX is impotent in influencing M2 and that applies, irrespective of whether being in the end or in the short-run. Common sense would suggest that as equity market posts higher returns, this generates a switch away from broad money holdings. However, in Mauritius, the cultural aspects predominate over the financial aspects. In fact, only high net worth individuals and educated persons are expected to have recourse towards the local equity market for the investments while the majority clings towards bank deposits.

Inflation rate is found to entail behind a negative long-run effect on broad money holdings with the elasticity hovering around 0.65 per cent. Such a negative relationship may be because as the inflation rate rises, people have higher preference for physical assets that constitute the best hedges against inflation relative to money balances. Indeed, in the case for Cameroon, Nachega (2001) states that "high inflation elasticities are generally expected in developing countries as the range of financial instruments outside money is very limited and real assets represent a substantial part of the public's portfolio". Moreover, Wu (2009) also finds that inflation has a significantly negative impact on the money demand in the case of China. Under foreign asset substitution, unfortunately, it clearly transpires that, independent of whether the focus is on the shortrun or in the long run, LIBORUSD is not statistically significant. Hence, foreign interest rate does not really affect the level of broad money demand in Mauritius. Interestingly, however, in the short-run, the one-period lagged difference of the USD generates a negative impact on broad money. More specifically, a $1 \%$ change in the one-period lagged difference of USD trails behind about $13 \%$ change in broad money. Above all, the economic significance is much higher than that of the three month Treasury bill yield, clearing showing that foreign exchange rate movements in US Dollar bears some direct effects on local monetary aggregates in the short-run. The positive effect may be explained by the fact that as Mauritians expect a depreciating rupee since the rupee has been structurally been depreciating over time, they demand more money to buy assets denominated in US Dollar. Overall, findings suggest that foreign asset substitution works mainly via the exchange rate channel rather than interest rate medium. Parameter constancy constitutes a critical issue whenever estimate the money demand function. Indeed, for an effective implementation of monetary policy, it is of paramount significance to have a stable money demand function. Moreover, Wu (2009) states that "what is being sought in a stable demand function is a set of necessary conditions for money to exert a predictable influence on the economy so that the central bank's control of money supply can be a useful instrument of economic policy". Parameter constancy is assessed using post estimation diagnostic tests. The estimated VECM is stable since nearly all the roots have modulus less than one and lie inside the unit circle as depicted in figure 1 in the appendix section so that impulse response and variance decomposition results are valid. Moreover, the diagnostic test results on the residual suggest no problem of serial correlation under serial correlation LM tests as shown in table 6 in the appendix section. Moreover, table 7 in the appendix part clearly shows that no autocorrelation is present in case of the VEC Residual Portmanteau Tests for Autocorrelations. Above all, VEC Residual Heteroskedasticity Tests show that residuals are not heteroscedastic whether in case of no cross terms (table 8 in the appendix) or cross terms (table 9 in the appendix). Overall, therefore these post-estimation diagnostic tests imply that the Mauritian money demand 
estimation is not only robust but also stable for the period under review. However, only normality conditions were violated.

Figure 2

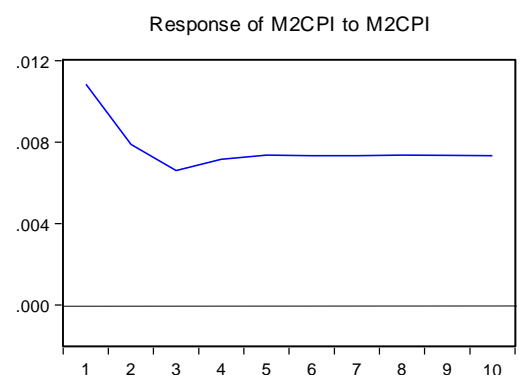

Figure 3

Percent M2CPI variance due to $\mathrm{M} 2 \mathrm{CPI}$

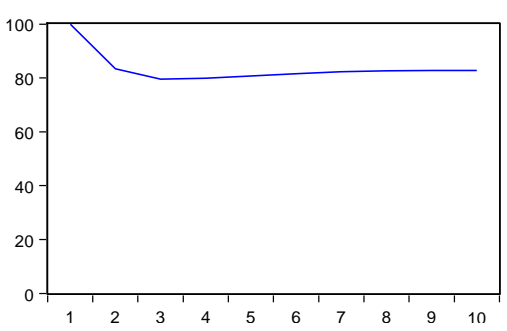

Response to Cholesky One S.D. Innovations Response of $\mathrm{M} 2 \mathrm{CPI}$ to GDPCPI

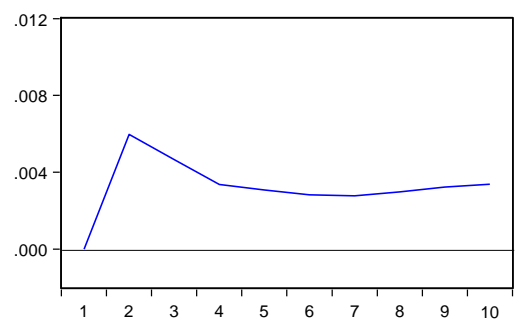

Variance Decomposition

Percent M2CPI variance due to GDPCPI

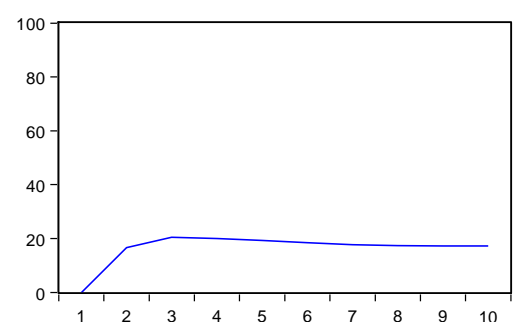

Response of $\mathrm{M} 2 \mathrm{CPI}$ to $\mathrm{CPI}$

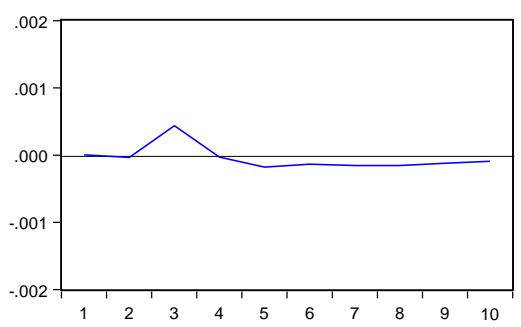

An alternative way to studying the short-run dynamics and co movements among the variables is to examine the impulse response and variance decomposition functions from the VECM model. This approach allows us to investigate the impact of different types of shocks on the variables in the model. Each innovation was obtained by a standard Choleski decomposition. Under variance decomposition as shown in figure 3, it surfaces that a shock in GDP accounts for about 20 per cent of the variance in M2, which is higher than that of CPI (below 0.1 per cent). Under impulse response function as depicted in figure 2, it transpires that though the adjustment time is similar for both GDP and CPI, nevertheless, the impact is again higher for GDP than for CPI. Results are shown in figure 2 and 3, respectively.

\section{Conclusion}

The current study probes into the money demand function in Mauritius. The findings suggest a stable money demand function in Mauritius with an estimated income elasticity of 2.80 per cent. In the case of developing countries, it is widely acknowledged by economists (see Fry, 1978; and Friedman and Schwartz, 1963) that the income elasticity of demand for money is greater than one. The estimated money demand function is deemed stable based on properties of the VECM model. No serial correlation, absence of heteroscedasticity, roots of AR function lying inside the unit circle though only normality conditions violated like in previous empirical studies, all justify a stable money demand function in Mauritius. Above all, the slow speed of adjustment for VECM is in line with empirical results derived for developing countries. The negative impact of inflation clearly shows that, in Mauritius, high inflation induces the holdings of more physical assets as they constitute the best insulation against rising prices in the long run. Foreign asset substitution works mainly via the exchange rate rather than interest rate movements with a positive impact noted since economic agents usually anticipate a depreciating rupee vis-à-vis the US Dollar. Many important policy implications can be drawn from the above findings. First, based on the derived stable money demand function in Mauritius, monetary targeting can still be used since it is optimal. This might provide justification for the monetary authority to target broad money or that the money demand function can still be used in conjunction with current monetary policy framework for monetary policy decisions. However, the low adjustment coefficient 
under ECM signifies that monetary targeting can at best be applied over a long-term rather than a short-term horizon.

Though the low adjustment coefficient under ECM lends support to the shift made by Bank of Mauritius from a policy that centered on monetary aggregates towards interest rates targeting as being rightly justified, yet, Standardizes (2010) recently shows that there is weak interest rate transmission mechanism in Mauritius. Hence, the second implication of this paper is that the implementation of monetary policy is indeed a hard nut to crack for a small country where structural changes happen to constitute a common feature. This further means that the ripe time has still not yet come. Third, the study further shows like Wu (2009) that data should not be seasonally adjusted to preserve their short-term dynamics and thereby sieve out the true essence of relationships that subsist among the variables in the system. Rather, seasonal dummies are used but none is found to be statistically significant. Fourth, the low adjustment coefficient under ECM may point out the lack of asset sophistication in Mauritius, i.e., other forms of assets other than M2. Consequently, this may further signal that Mauritius is endowed with low level of financial deepening with a more or less repressed financial system. In a parallel manner, the high-income elasticity in Mauritius is mainly attributable to a limited scope for financial asset substitution or that Mauritius has still an underdeveloped or shallow financial system with monetization moving faster than output. Fifth, an interesting aspect of the results is that even though the Mauritian economy has undergone a number of important structural changes during the studied period such as distinct monetary policy frameworks, the long-run relationships between the examined macroeconomic and financial aggregates are fairly stable and consistent with economic theory. Beyond that, the results further show that monetary aggregates in Mauritius were not really affected by the US Subprime crisis, in line with the fact that none of our banks had exposure to toxic assets. Hence, this study indirectly shows that monetary aggregates of the Mauritian economy remained healthy even post the US Subprime crisis. Finally, should Mauritius further develop its financial system, this is expected to generate a decline in income elasticity. To conclude, it is of paramount significance to bear in mind that, the experience of policy-makers has a greater propensity to outperform results derived from econometric modeling since they best know the diverse operating mechanisms of their financial system. Nonetheless, the beauty of modeling for policy decisions lies in the extent to which econometrics can cater for the distinctive features of an economy under investigation to bring out important results, which are usually not visible under normal analysis.

\section{Appendix \\ Figure 1}

Inverse Roots of AR Characteristic Polynomial

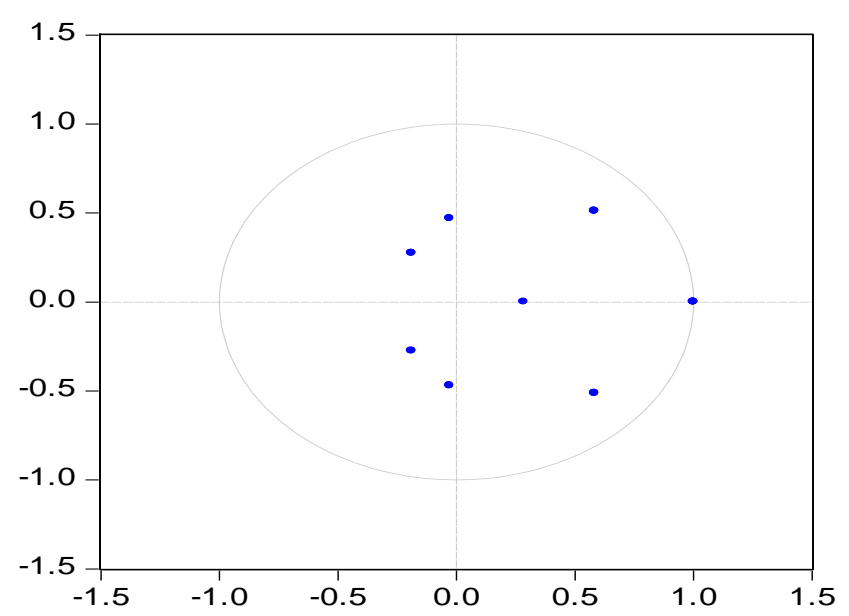




\begin{tabular}{lll}
\multicolumn{3}{l}{ Table 6: VEC Residual Serial Correlation LM Tests } \\
\hline \multicolumn{3}{l}{ Null Hypothesis: no serial correlation at lag order h } \\
\hline Date: $05 / 05 / 10$ & Time: $11: 44$ \\
Sample: & 2000M01 & 2009M09, Included observations: 114 \\
Lags & LM-Stat & Prob \\
1 & 13.26033 & 0.1512 \\
2 & 16.70197 & 0.0536 \\
3 & 17.45934 & 0.0420 \\
4 & 12.04866 & 0.2106 \\
5 & 13.79470 & 0.1298 \\
6 & 8.315142 & 0.5027 \\
7 & 16.38850 & 0.0592 \\
8 & 17.92420 & 0.0361 \\
9 & 15.33668 & 0.0821 \\
10 & 9.164431 & 0.4222 \\
11 & 5.509251 & 0.7879 \\
12 & 133.4576 & 0.0000 \\
Probs from chi-square with $9 \mathrm{df}$. \\
\hline
\end{tabular}

Table 7: VEC Residual Portmanteau Tests for Autocorrelations

\begin{tabular}{|c|c|c|c|c|c|}
\hline \\
\hline \multicolumn{6}{|c|}{ Date: $05 / 05 / 10$ Time: $11: 44$} \\
\hline \multicolumn{6}{|c|}{ Sample: 2000M01 2009M09, Included observations: 114} \\
\hline Lags & Q-Stat & Prob. & Adj Q-Stat & Prob. & $\mathrm{df}$ \\
\hline 1 & 1.462988 & $\mathrm{NA}^{*}$ & 1.475935 & $\mathrm{NA}^{*}$ & NA* \\
\hline 2 & 5.631072 & NA* & 5.718449 & NA* & NA* \\
\hline 3 & 16.02256 & 0.3806 & 16.39079 & 0.3566 & 15 \\
\hline 4 & 26.88150 & 0.3100 & 27.64460 & 0.2753 & 24 \\
\hline 5 & 39.36273 & 0.2065 & 40.69836 & 0.1677 & 33 \\
\hline 6 & 47.51795 & 0.2580 & 49.30665 & 0.2041 & 42 \\
\hline 7 & 62.53012 & 0.1292 & 65.30092 & 0.0859 & 51 \\
\hline 8 & 79.04241 & 0.0503 & 83.05942 & 0.0260 & 60 \\
\hline 9 & 91.44980 & 0.0366 & 96.53031 & 0.0160 & 69 \\
\hline 10 & 99.62288 & 0.0500 & 105.4893 & 0.0208 & 78 \\
\hline 11 & 104.6995 & 0.0951 & 111.1080 & 0.0417 & 87 \\
\hline 12 & 182.5057 & 0.0000 & 198.0679 & 0.0000 & 96 \\
\hline
\end{tabular}

*The test is valid only for lags larger than the VAR lag order. $\mathrm{df}$ is degrees of freedom for (approximate) chi-square distribution * df and Prob. may not be valid for models with exogenous variables

Table 8: VEC Residual Heteroskedasticity Tests: No Cross Terms (only levels and squares) Date: 05/05/10 Time: 11:45

Sample: 2000M01 2009M09, Included observations: 114

Joint test:

\begin{tabular}{|c|c|c|c|c|c|}
\hline Chi-sq & $\mathrm{df}$ & Prob. & & & \\
\hline 142.4229 & 132 & 0.2527 & & & \\
\hline Individua & omponents: & & & & \\
\hline Dependent & R-squared & $F(22,91)$ & Prob. & Chi-sq(22) & Prob. \\
\hline res1*res1 & 0.145070 & 0.701885 & 0.8267 & 16.53800 & 0.7883 \\
\hline res2*res2 & 0.428279 & 3.098574 & 0.0001 & 48.82384 & 0.0008 \\
\hline res3*res3 & 0.167820 & 0.834153 & 0.6766 & 19.13151 & 0.6372 \\
\hline res $2 *$ res 1 & 0.148219 & 0.719770 & 0.8084 & 16.89695 & 0.7690 \\
\hline res3*res1 & 0.108327 & 0.502517 & 0.9661 & 12.34930 & 0.9497 \\
\hline res3*res2 & 0.153801 & 0.751808 & 0.7737 & 17.53336 & 0.7333 \\
\hline
\end{tabular}


Table 9: VEC Residual Heteroskedasticity Tests: Includes Cross Terms

\begin{tabular}{|c|c|c|c|c|c|}
\hline \multicolumn{6}{|c|}{ Date: $05 / 05 / 10$ Time: $11: 45$} \\
\hline \multicolumn{6}{|c|}{ Sample: 2000M01 2009M09 } \\
\hline \multicolumn{6}{|c|}{$\begin{array}{l}\text { Included observations: } 114 \\
\text { Joint test: }\end{array}$} \\
\hline Chi-sq & $\mathrm{df}$ & Prob. & & & \\
\hline 455.6236 & 462 & 0.5749 & & & \\
\hline \multicolumn{6}{|c|}{ Individual components: } \\
\hline Dependent & R-squared & $F(77,36)$ & Prob. & Chi-sq(77) & Prob. \\
\hline res1*res1 & 0.484385 & 0.439215 & 0.9987 & 55.21991 & 0.9713 \\
\hline res2*res2 & 0.822576 & 2.167583 & 0.0059 & 93.77368 & 0.0939 \\
\hline res3*res3 & 0.650810 & 0.871372 & 0.6979 & 74.19232 & 0.5695 \\
\hline res $2 *$ res 1 & 0.595951 & 0.689584 & 0.9125 & 67.93836 & 0.7601 \\
\hline res3*res1 & 0.620413 & 0.764154 & 0.8380 & 70.72707 & 0.6793 \\
\hline res3*res 2 & 0.569875 & 0.619437 & 0.9596 & 64.96578 & 0.8342 \\
\hline
\end{tabular}

\section{References}

Anuar, A. R. (1986). The Demand for Money in Malaysia, 1965(1)-1984(4). Analisis, 1(1), 27-40.

Baharumshah, A. Z. (2004). Stock Prices and Long Run Demand for Money Evidence from Malaysia. International Economics Journal, 18(3), 389-407.

Bahmani-Oskooee, M. \& Malixi, M. (1991). Exchange rate sensitivity of the demand for money in developing countries. Applied Economics, 23(8), 1377-1383.

Baumol, W. J. (1952). The Transactions Demand for Cash: An Inventory Theoretic Approach. The Quarterly Journal of Economics, 66, 545-56.

Chowdhury, A. R. (1995). The Demand for money in a Small Open Economy: The Case of Switzerland. Open Economies Review, 6, 131-144.

Civcir, I. (2003). Broad Money Demand and Currency Substitution in Turkey. The Journal of Developing Countries, 36(1), 1-19.

Dahalan, J. (2004). The Uncertainty of the U.S. and Japanese Interest Rates and Its Effect on Money Demand in Malaysia. International Journal of Management Studies, 11(1), 71-89.

Dekle, R. \& Pradhan, M. (1997). Financial Liberalization and Money Demand in the ASEAN Countries. International Journal of Finance \& Economics, 4(3), 205-15.

Ericsson, N. R. \& Sharma, S. (1996). Broad Money and Financial Liberalization in Greece, IMF Working Paper 96/62, International Monetary Fund, Washington, D.C.

Ericsson, N. R., Hendry, D. F. \& Tran, H. (1994). Co integration, Seasonality, Encompassing and the Demand for Money in the United Kingdom. In: Hargreaves, C. (Ed.). Non-stationary Time-series Analysis and Co integration, 179-224. Oxford: Oxford University Press.

Fisher, I. (1911). The Purchasing Power of Money, MacMillan, New York.

Friedman, M. \& Schwartz, A. (1963). A Monetary History of the United States, Princeton: Princeton University Press.

Friedman, M. (1969). The Optimum Quantity of Money. In The Optimum Quantity of Money and Other Essays. Chicago: Aldine Publishing Company.

Fry, M. (1978). Money and Capital or Financial Deepening in Economic Development. Journal of Money, Credit and Banking, 10(4), 464-475.

Habibullah, M. S. \& Ghaffar, R. A. (1989). The Demand for Currency and Demand Deposits in Malaysia: An Empirical Evidence. Analisis, 3(1), 111-122.

Habibullah, M. S. (1987). Income Expectations and the Demand for Money in Malaysia: Some Empirical Evidence. Analisis, 2(1), 61-71.

Johansen, S. (1991). Estimation and Hypothesis Testing of Co integration Vectors in Gaussian Vector Autoregressive Models. Econometrica, 59, 1551-1580.

Keynes, J. M. (1936). The General Theory of Employment, Interest and Money, London: Macmillan.

Keynes, J. M. (1930). A Treatise on Money, 1, the Pure Theory of Money, London, Macmillan.

Keynes, J. M. (1936). The General Theory of Employment, Interest and Money. 
Knell, M. \& Stix, H. (2004). Three Decades of Money Demand Studies, Some Differences and Remarkable Similarities, OeNB Working Paper $\mathrm{N}^{\circ} 88$.

Laidler, D. E. W. (1993). The Demand for Money: Theories, Evidence and Problems, New York, Haper Collins Collage Publishers.

Majid, M. Z. A. (2004). Reassessing the Stability of Broad Money Demand in Malaysia, Bank Negara Malaysia Discussion Papers, Kuala Lumpur.

Marashdeh, 0. (1997). The Demand for Money in an Open Economy: the Case of Malaysia presented at the Southern Finance Association Annual Meeting, 19-22 November 1997, Baltimore, Maryland, USA.

Nachega, J. (2001). Financial Liberalization, Money Demand, and Inflation in Uganda. IMF Working Paper 01/118, International Monetary Fund, Washington, D.C.

Pigou, A. C. (1917). The value of money. Quarterly Journal of Economics, 32, (1917-1918), Reprinted in Readings in Monetary Theory, F. A. Lutz, \& L. W. Mints (Eds.). Philadelphia, 2, 162-183.

Ramlall, I. (2010). Do Credit and Debit Cards Induce an Evaporation of Cash in Mauritius? International Research Journal of Finance and Economics, 36, 16-24.

Rasche, R. N. \& Johannes, J. M. (1987). Controlling the growth of monetary aggregates, Boston MA, Kluwer Academic Publisher.

Schumpeter, J. A. (1954). History of Economic Analysis. Allen \& Unwin London.

Simmons, R. (1992). An Error-Correction Approach to Demand for Money in Five African Developing Countries. Journal of Economic Studies, 19, 29-47.

Sriram, S. S. (1999). Survey of Literature on Demand for Money: Theoretical and Empirical Work with Special Reference to Error-Correction Models. IMF Working Paper No. 99/64, International Monetary Fund, Washington, D.C.

Sriram, S. S. (2001). A Survey of Recent Empirical Money Demand Studies. IMF Staff Papers, 47(3), 334-65.

Taylor, M. P. (1986). From the general to the specific: The demand for M2 in three European countries. Empirical Economics, 11, 243-61.

Tobin, J. (1956). The Interest Elasticity of Transactions Demand for Cash. Review of Economics and Statistics, $38,241-47$.

Tsangarides, G. T. (2010). Monetary Policy Transmission in Mauritius Using a VAR Analysis. IMF Working Paper 10/36, International Monetary Fund, Washington, D.C.

Wallis, K. F. (1974). Seasonal Adjustment and Relations between Variables. Journal of the American Statistical Association, 69, 18-31.

Wu, G. (2009). Broad Money Demand and Asset Substitution in China. IMF Working Papers 09/131, International Monetary Fund, Washington, D.C. 